\title{
ORC6 wt Allele
}

National Cancer Institute

\section{Source}

National Cancer Institute. ORC6 wt Allele. NCI Thesaurus. Code C52317.

Human ORC6 wild-type allele is located in the vicinity of $16 q 11.2$ and is approximately $9 \mathrm{~kb}$ in length. This allele, which encodes orig in recognition complex subunit 6 protein, is involved in the modulation of chromosome replication. 